\title{
A Magyar Királyi Honvédség páncélos szervezeteinek részvétele a Szovjetunió elleni hadmüveletben, 1941-ben
}

A Szovjetunió ellen, szárazföldi hadműveletekre, 1941 júniusában egy hadműveleti csoportot hoztak létre. A Kárpát-csoport vezetésével Szombathelyi Ferenc altábornagyot bízták meg. A parancsnoksága alá a VIII. és a gyorshadtest tartoztak. A VIII. hadtest az 1. hegyivadászés a 8. határvadászdandárokból állt. Az 1. hegyivadászdandár, Felk Jenő vezérőrnagy parancsnoksága alatt 4 hegyivadász-zászlóaljból, egy hegyi tüzérosztályból, egyegy hegyihuszár-, páncéltörőágyús, motorkerékpáros, híradó- és árkász-századból, továbbá egy páncélgépkocsiszakaszból állt. A páncélgépkocsi-szakasznak három 39M Csaba páncélgépkocsija volt.

A 8. határvadász-dandár Rakovszky György vezérőrnagy vezetésével 6 határvadász-zászlóaljból, 3 tüzérosztályból állt és megerősítésre került a VIII. kerékpáros zászlóaljjal.

A gyorshadtest parancsnoka vitéz dálnoki Miklós Béla vezérőrnagy volt, és a hadműveleti területre 3 dandárjával, az 1. lovas és az 1. és 2. gépkocsizó lövészdandárjával vonult el. A gyorshadtest megerősítésre került az I., V., VIII. közepes gépvontatású tüzérosztályokkal, a VI. és VII. kerékpáros, a 152. műszaki és a 150. híradó-zászlóaljakkal.

1. ábra. A H-309-es rendszámú 38M Toldi könnyű harckocsi még az 1. felderítő-zászlóalj jelzésével. Ekkor már a

9. könnyűharckocsi-zászlóalj állományába tartozott

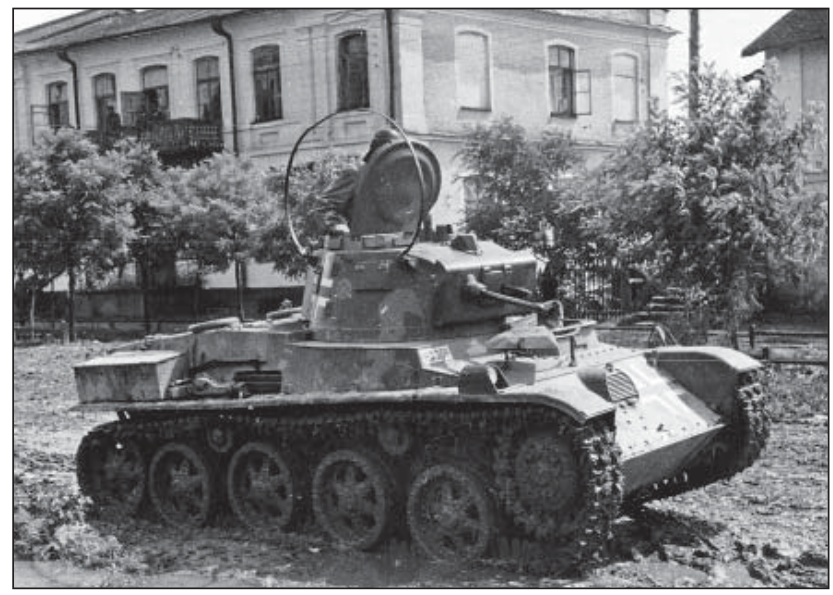

ÖSSZEFOGLALÁS: A Magyar Királyi Honvédség a második világháború során első ízben az 1941. évi Szovjetunió elleni támadó hadműveletben képviselte a korszerü gépesített hadviselést. A gyorshadtest kötelékében tevékenykedő gépkocsizó dandárok elsőként vetettek harcba Toldi könnyűharckocsin alapuló harckocsizászlóaljakat. A szovjet csapatok többezer km-es üldözése során néhány hónap alatt kiforrtak a magyar páncélos hadviselés elvei.

KULCSSZAVAK: Magyar Királyi Honvédség, gyorshadtest, gépkocsizódandár, Toldi könnyüharckocsi

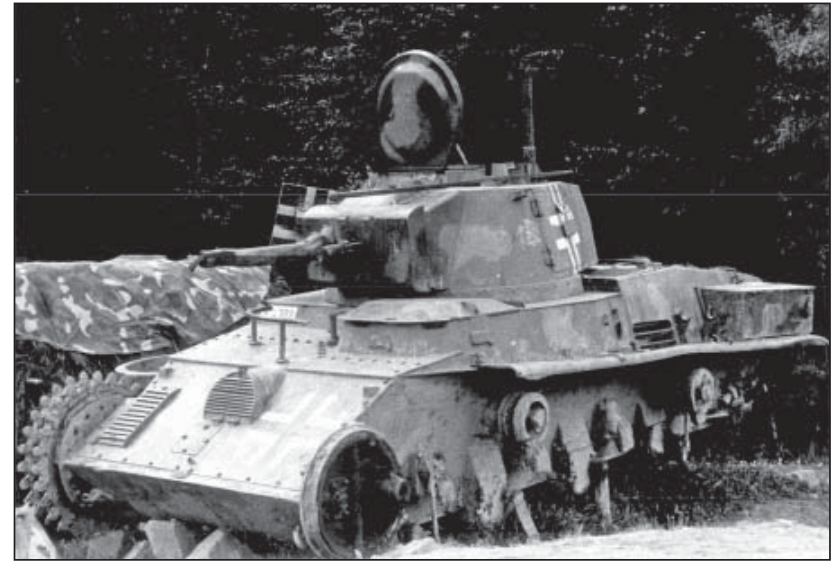

2. ábra. Egy javításra váró $38 \mathrm{M}$ Toldi könnyű harckocsi; a harcjármúveket igyekeztek a tábori javítómühelyekben harcképessé tenni

Az 1. gépkocsizó lövészdandárt Major Jenő vezérőrnagy vezette, a 2. gépkocsizó lövészdandár parancsnoka Vörös János vezérőrnagy volt, míg az 1. lovasdandár élén Vattay Antal vezérőrnagy állt.

A gyorshadtest a mozgósítási parancsot a békehelyőrségeiben kapta meg június 26-án. A csapatoknak nagyon kevés ideje volt a mozgósítás végrehajtására, mert június 29-ével kellett megkezdeniük a felvonulást a megindulási körzetekbe. A mozgósítás, a nem sokkal korábban befejeződött délvidéki hadműveletek miatt vontatottan haladt, a kivonuló csapatok nagyjából 75-80\%-os harcértékkel rendelkeztek.

Az új hadrendnek megfelelően a gépkocsizó lövészdandárok állományába már egy-egy könnyűharckocsi- és felderítő-zászlóalj tartozott. A lovasdandárok pedig egy lovas páncéloszászlóaljjal rendelkeztek. Az 1. gépkocsizó lövészdandár kötelekébe a 9. kerékpáros könnyűharckocsi-zászlóalj, a 2. gépkocsizó lövészdandár állományába pedig a 11. kerékpáros könnyűharckocsi-zászlóalj tartozott. A zászlóaljak elnevezése utalt az alakulatok átmeneti szervezeti formájára. A kerékpáros könnyűharckocsi-zászlóaljak a következő alegységekből álltak; zászlóaljtörzs (3 db 38M Toldi

ABSTRACT: It was the Royal Hungarian Army that, during the World War II, represented first the modern mechanized warfare in the offensive operation against the Soviet Union in 1941. The motorized brigades being active in the formation of the Rapid Corps first put into action tank battalions based on the Toldi light tanks. During running battle through several thousand kilometres against the Soviet troops, the principles of Hungarian armoured warfare matured within some months.

KEY WORDS: Royal Hungarian Army, Rapid Corps, motorized brigade, Toldi light tank 


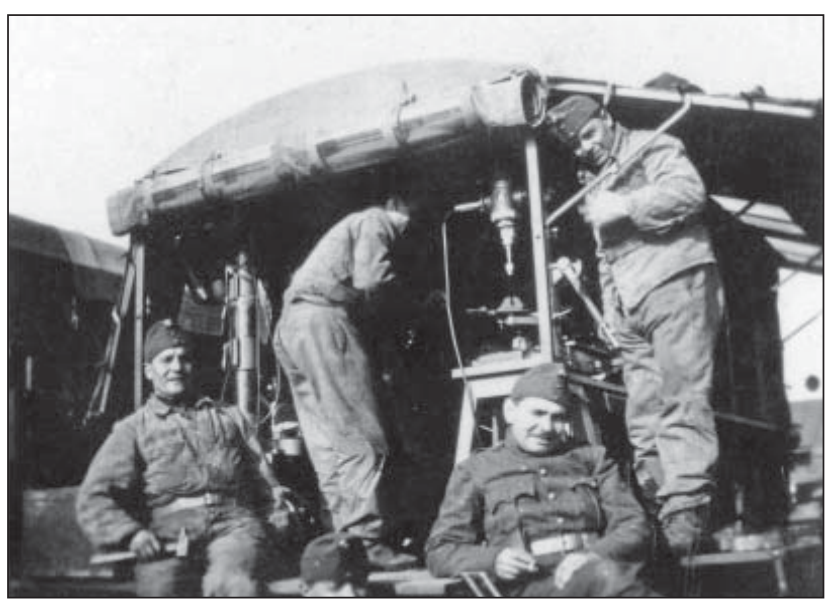

3. ábra. Magyar szeroszlop múhelygépkocsija munka közben

könnyű harckocsi), egy-egy árkász-, távbeszélő és műhelyszakasz, az 1., 2. kerékpáros és a 3., 4. könnyűharckocsi-századok (18-18 db 38M Toldi könnyű harckocsi).

1941. július 1-ei állapot szerint a 9. kerékpáros könnyűharckocsi-zászlóalj hadrendjébe 39 db 38M Toldi könnyű harckocsi, $52 \mathrm{db}$ tehergépjármü, $11 \mathrm{db}$ személygépkocsi, $37 \mathrm{db}$ motorkerékpár, $2 \mathrm{db}$ oldalkocsis motorkerékpár, 2 mentőautó, egy-egy üzemanyag-szállító és híradó-gépjármü tartozott. A kerékpáros századok egyenként $206 \mathrm{db}$ kerékpárral rendelkeztek. Minden kerékpáros könnyűharckocsi-zászlóalj rendelkezett egy-egy visszamaradó különítménnyel, 8 db 38M Toldi könnyű harckocsival a kiképzés és a tartalék képzésre.

$A z$ 1. és a 2. felderítő-zászlóaljak állományába egyenként, egy-egy páncélgépkocsi (16 db 39M Csaba páncélgépkocsi), gépkocsizó lövész-, motorkerékpáros és törzsszázad tartozott. A törzsszázad állománya egy-egy páncéltörő ágyús (36M 37 mm-es páncéltörő ágyú), távbeszélő, árkász- és műhelyszakaszból állt. A motorkerékpáros századok vegyes, zömében mozgósított polgári gépparkkal rendelkeztek, BMW R-75-ös, Zündapp 597c, CWS-MIII, Puch G350-es, CZ 175-ös, Zündapp DB200W, Ariel, Gilera motorkerékpárokkal. A bevonultatott civil motorkerékpárok meglehetősen rossz müszaki állapotban voltak, a motorkerékpáros századok a hadműveletek megindulása után hamarosan motorok nélkül maradtak.

Az 1. lovas páncéloszászlóalj állományába egy páncélgépkocsi-század (16 db 39M Csaba páncélgépkocsi) és két kisharckocsiszázad tartozott (9 db 38M Toldi könnyű harckocsival és $36 \mathrm{db} 35 \mathrm{M}$ FIAT Ansaldo kisharckocsival).

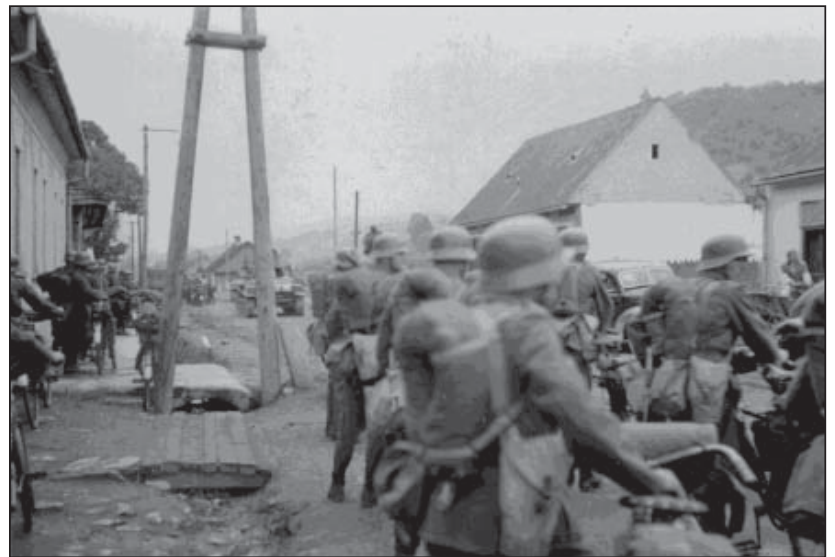

5. ábra. Kerékpáros csapatok és 38M Toldi könnyú harckocsik haladnak át a Tatár-hágón

Minden kisharckocsiszázad három kisharckocsi-szakaszszal (3×6 db 35M FIAT Ansaldo kisharckocsi) és egy könynyűharckocsi-szakasszal (4 db 38M Toldi könnyű harckocsi) rendelkezett. A 9. Toldi könnyű harckocsi zászlóalj a zászlóaljtörzshöz tartozott.

A gépkocsizó lövészdandárok állományába egy-egy, a lovasdandár állományába két kerékpáros zászlóalj tartozott. A négy kerékpáros zászlóalj, a 10., 12., 13., és 14. állományába egy-egy kisharckocsi-szakasz tartozott 6-6 db (öszszesen 24 db) 35M FIAT Ansaldo kisharckocsival.

A gyorshadtest a hadműveletek megindulásakor $508 \mathrm{db}$ 31M Solothurn golyószóróval, 168 db 07/31M Schwarzlose géppuskával, 52 db 36M 20 mm-es nehézpuskával, 12 db $36 \mathrm{M} 80 \mathrm{~mm}$-es aknavetővel, 80 db 36M 37 mm-es páncéltörő ágyúval, 60 db 36M 40 mm-es és 29M 8 cm-es Bofors légvédelmi löveggel és $90 \mathrm{db}$ tábori löveggel rendelkezett. A gyorshadtest páncélos ereje $81 \mathrm{db} 38 \mathrm{M}$ Toldi könnyű harckocsiból (más források szerint 87), 48 db 39M Csaba páncélgépkocsiból és $60 \mathrm{db} 35 \mathrm{M}$ FIAT Ansaldo kisharckocsiból állt.

A Kárpát-csoport 1941. június 28-án kezdte meg az előrenyomulást a rendkívül nehéz hegyi terepen a Kárpátokban, Volócnál. A visszavonuló szovjet csapatok mindenütt rombolták a mútárgyakat, hidakat, átereszeket, alagutakat. A Kárpátokban a Vörös Hadsereg utászai 21 hidat robbantottak fel. A magyar csapatok előretörését a heves esőzések és az ezt követő áradások is nehezítették.

A 2. gépkocsizó lövészdandár 1941. július 3-án esett át a tűzkeresztségen, amikor elfoglalta Delatyint. A dandár csapatai, heves harcok után július 5-én bevonultak Horo-

\section{4. ábra. 39M Csaba páncélgépkocsi-szakasz és Ford tehergépkocsi a támadás megindulása előtt, a szovjet-magyar határnál}

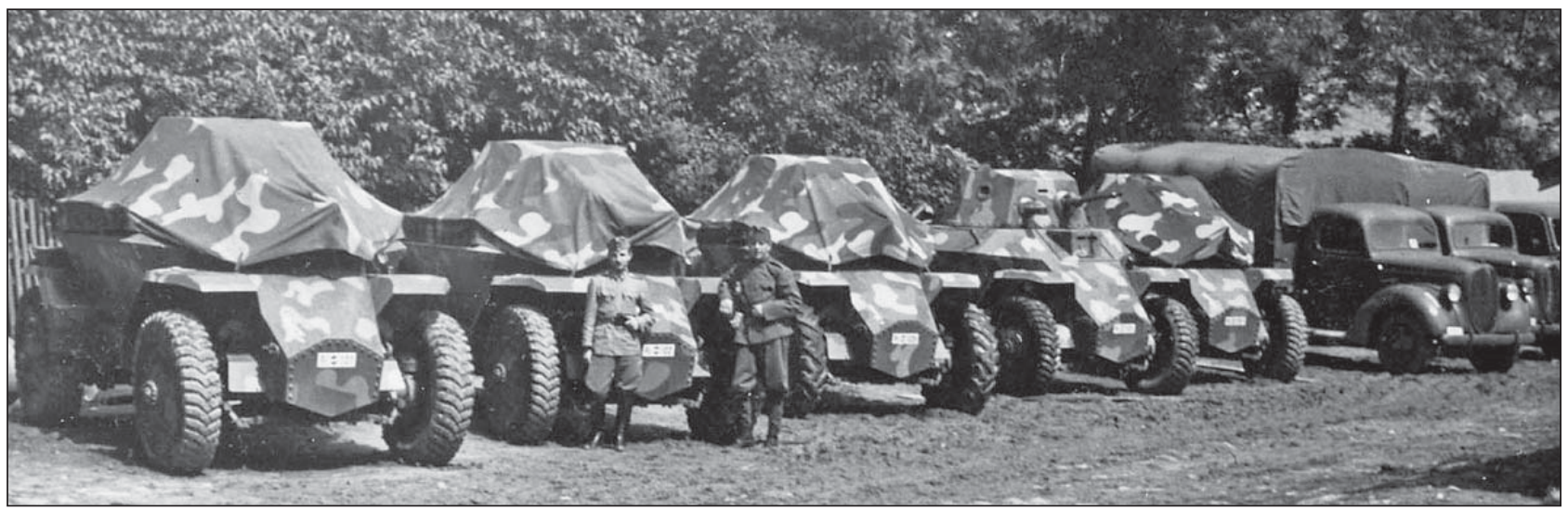




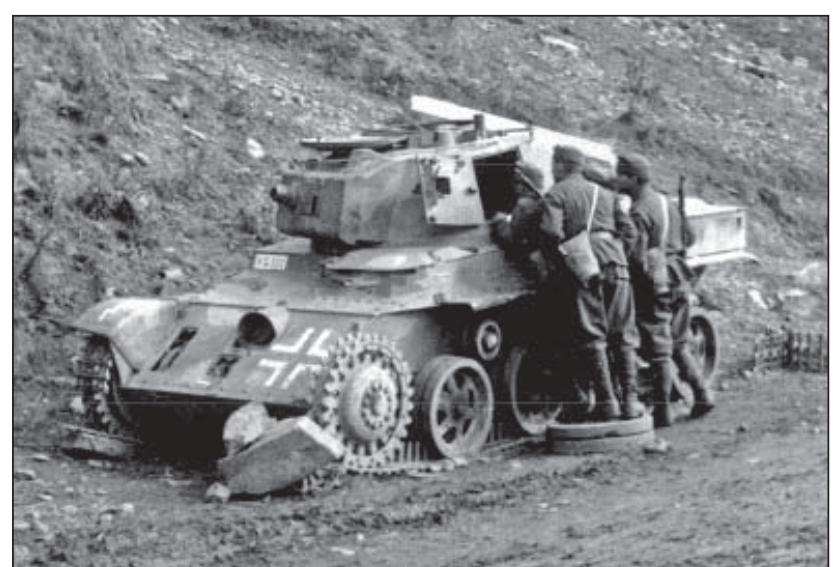

6. ábra. A H-322-es rendszámú, aknára futott $38 \mathrm{M}$ Toldi könnyú harckocsi, kiszerelt fegyverzettel

denkára. A VIII. kerékpáros zászlóaljat, mint elővédet vetették be a Siret folyón lévő hidak elfoglalására és a Zbruch folyó felé visszavonuló szovjet erők megfigyelésére.

1941. július 9-ével a gyorshadtestet alárendelték a német Dél Hadseregcsoportnak a 17. német hadsereg támogatására, a VIII. hadtest visszamaradt az elfoglalt területeken megszálló, biztosító feladatok ellátására.

A magyar csapatok feladata az összeköttetés fenntartása a 17. német, a 3 . román és 11 . német hadsereg között, illetve a visszavonuló szovjet egységek üldözése volt. A gyorshadtest vezetése kidolgozott egy harceljárást a szovjet csapatok üldözésére. A gépkocsizó lövészdandárok a támadási irányban az egymással párhuzamosan futó utakon kerültek bevetésre, míg a lovasdandár csapatai a két gépkocsizó lövészdandár közötti területen nyomult előre. A gyatra minőségű utakon, a heves esőzésben a lovasság gyorsabban tudott előrejutni, mint a kerékpáros és gépesített egységek. A gépkocsizó lövészdandárok zöme előtt, elővédként a felderítő-zászlóalj csapatai haladtak, megerősítve könnyű harckocsi, 40 mm-es Bofors légvédelmi gépágyú-, árkász-, forgalomirányító szakaszokkal és egy-egy gépkocsizó lövészszázaddal és könnyű tarackos üteggel. A második lépcsőben egy gépkocsizó lövészzászlóalj haladt, őket követte a dandár zöme és végül az utóvéd.

A visszavonuló szovjet csapatok elszántan harcoltak az előrenyomuló honvédek ellen. A magyar elővédeket számtalan esetben átengedték magukon a Vörös Hadsereg ka-

7. ábra. Az 1. felderítő-zászlóalj Pc-125-ös rendszámú 39M Csaba páncélgépkocsijának kiégett roncsa, a rogaznai úton

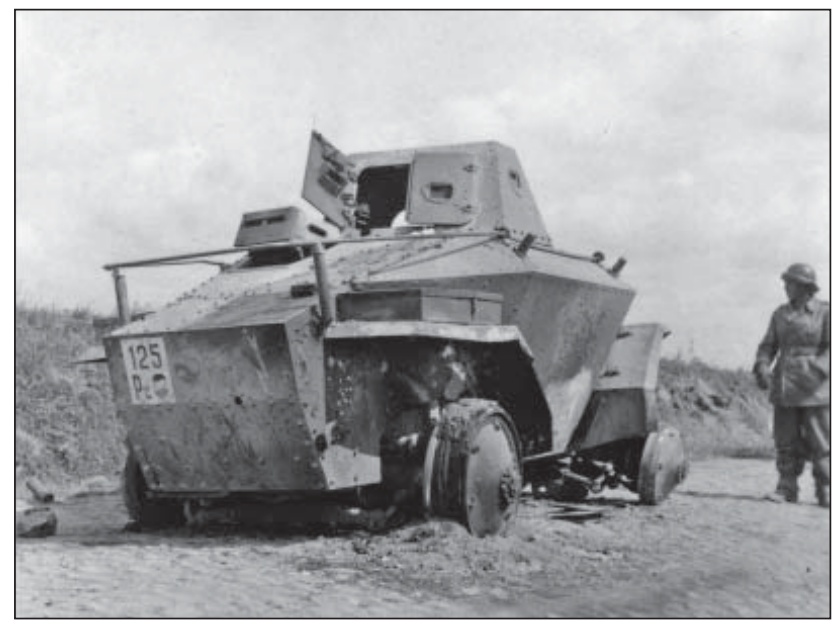

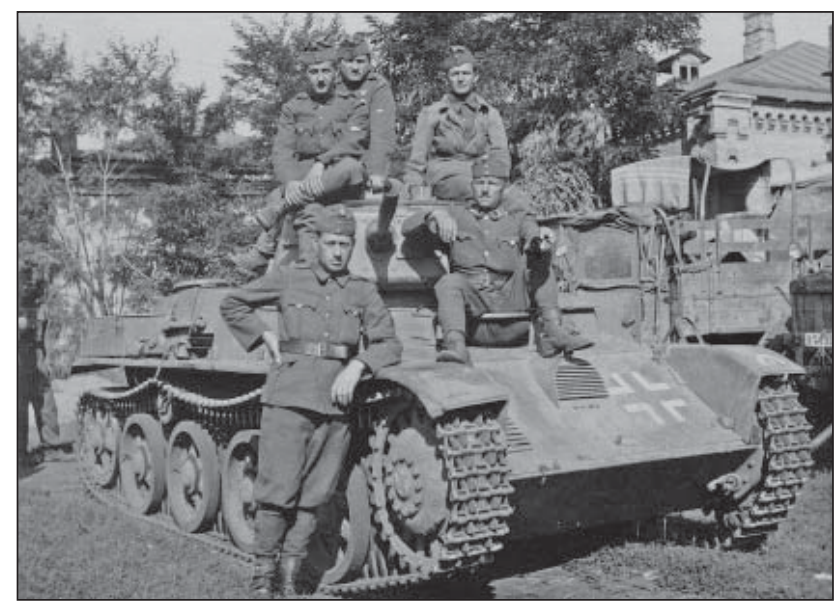

8. ábra. 38M Toldi könnyú harckocsi, az 1. lovas páncéloszászlóalj jelzésével

tonái, majd hátba támadták őket. Váratlan ellencsapásokat, rajtaütéseket hajtottak végre a honvéd alakulatok ellen. A mozgó háború miatt nem voltak szilárd arcvonalak, nem lehetett tudni, hogy a hirtelen felbukkanó csapatok saját, vagy ellenséges erőkhöz tartoztak-e. A hirtelen, a semmiből kialakuló összecsapások, gyors előrenyomulások és visszavonulások, kitérések tarkították az általános előrenyomulást. A magyar csapatok sokszor kerültek szembe helyi túlerővel, kényszerültek védekezésre. A gyorshadtest vezetése a páncélos erőket, elsősorban a könnyű harckocsikat szakasz és század kötelékben a helyi ellenállások megtörésére, bekerített saját csapatok felmentésére, támogatására vetették be. A 38M Toldi könnyű harckocsik jó terepjáró képességgel rendelkeztek, gyorsak voltak, de páncélzatuk és fegyverzetük nem tette őket kimondottan alkalmassá harckocsik és páncéltörő ágyúk elleni harcra. A gyorshadtest által használt gépjárművek közül maradéktalanul a 38M Botond terepjáró gépkocsi váltotta be a hozzá füzött reményeket.

Az első tényleges háborús helyzetben a magyar páncélos egységeket sokszor a meglévő utasítások, harceljárások figyelembevétele nélkül alkalmazták, sem az elöljárók, sem a páncélos alegységparancsnokok nem ismerték még a saját technika lehetőségeit, képességeit és az ellenség páncélelhárító eszközeit. Sokszor az előrenyomuló magyar erők elhanyagolták a felderítést és váratlan helyzetekbe kerültek, ezzel tovább növelték a veszteségeiket.

Az előrenyomuló magyar csapatok logisztikai támogatása is rendkívül nehézkes volt, a kevés és rossz minőségü utakon a csapatok feltorlódtak. A bevonultatott polgári tehergépkocsikból álló ellátó oszlopoknál nagyon sok jármű kiesett a sorból, nem bírták a rossz utakat, nem volt megfelelő mennyiségű műszaki mentő-, javítókapacitás sem. Előfordult, hogy a csapatokat légi úton kellett élelemmel ellátni.

1941. július 11-én a gyorshadtest parancsnoka elrendelte a lovasság előrevonását, mert a gépkocsizó dandárok elakadtak a mély sárban. Július 11. és 13. között a huszárok Zwanczyk és Kurilowa térségében harcoltak. Egy kimutatás szerint a gyorshadtest csapatai július 10. és 12. között 13 harckocsit, 12 löveget és 11 gépjárművet zsákmányoltak a visszavonuló szovjet csapatoktól.

1941. július 13-án a 9. kerékpáros könnyűharckocsizászlóalj 3. könnyűharckocsi-százada bevetésre került Nowa Uszicanál a német 101. gyalogos hadosztály támogatására. A 3. könnyüharckocsi-századot Kárpáthy Tibor százados vezette harcba az Antonovka és Filjanovka kö- 


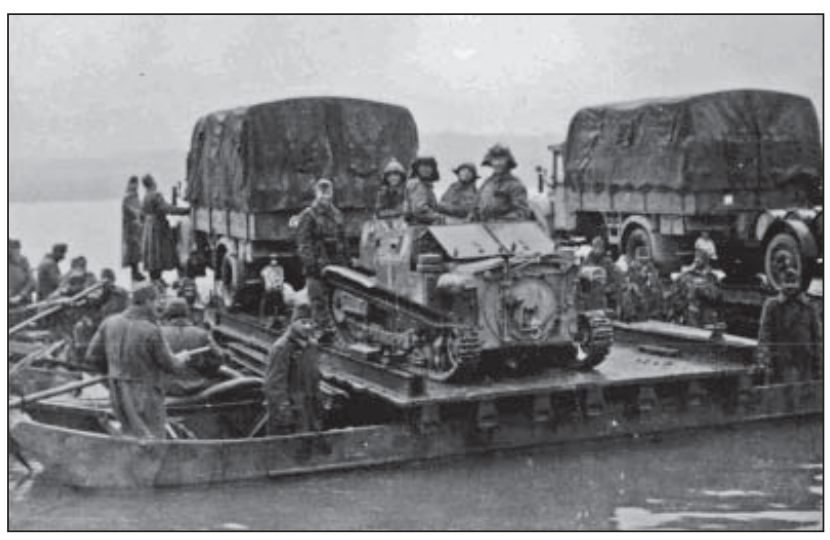

9. ábra. Az 1. lovas páncélos zászlóalj 35M FIAT Ansaldo kisharckocsijai a Dnyeper folyón kelnek át

zötti úton, hogy áttörjék a szovjet védelmet. Egy álcázott szovjet páncéltörő ágyú 200-300 méteres távolságról kilőtte a századparancsnoki harckocsit, amely azonnal megállt. A harcjármű-vezető és a toronylövész elesett, Kárpáthy százados súlyosan megsebesült. A parancsnoki Toldi a harcmezőn a következő, végzetes találatra várt, amikor Habel Pál hadapród őrmester könnyű harckocsiját a védtelen századparancsnoki jármű és a szovjet páncéltörő löveg közé kormányozta. A következő lövés már Habel hadapród őrmester Toldiját érte, elpusztítva ezzel a teljes személyzetét, de a századparancsnokot sikerült kimenteni a roncsból. A támadás során a 3 . könnyűharckocsi-század súlyos veszteséget szenvedett, $6 \mathrm{db}$ harckocsiját vesztette el és 9 fő halt hősi halált. Ismerjük az ebben az összecsapásban kilőtt 38M Toldi könnyű harckocsik rendszámát is: $\mathrm{H}-306$, $-314,-315,-316,-397,-399$.

Július 15. és 17. között a VI. és a VII. kerékpáros zászlóalj egy rövid pihenőt tarthatott Kamenyec-Podolskban, az állomány teljesen kimerült a megerőltető hegyi menetek miatt, a kerékpárok tönkrementek, állandó hiány volt kerékpárgumikban.

A gépjármű és harci technika nagyfokú elhasználódása és a szerelőkapacitás hiánya miatt július 18-ával a Weiss Manfréd, Ganz és MÁVAG gyáraktól civil szerelőkből álló javítócsoportokat küldtek a frontra. Egy külön civil javítórészleg a $30 \mathrm{db}$ müszaki hibás 35M FIAT Ansaldo kisharckocsi javításán fáradozott.

A német hadvezetés utasítására az 1. gépkocsizó lövészdandár és az 1. lovasdandár megkezdte az elöretörést a Sztálin-vonal irányába. A nehéz, mocsaras, folyókkal szabdalt terepen Dunajec térségéből indított támadással az 1. gépkocsizó lövészdandár július 19-én Barnál áttörte a szovjet vonalakat. A lovasdandár gépesített és kerékpáros egységei az utakon, míg a huszárezredek a terepen nyomultak előre. Az 1941. július 19. és 22. közötti harcokban az 1. gépkocsizó lövészdandár csapatai 21 szovjet harckocsit, 16 páncélgépkocsit és 12 löveget tettek harcképtelenné, illetve zsákmányoltak. A magyar honvédek 26 halottat, 50 sebesültet és 10 eltüntet vesztettek a harcok során. $15 \mathrm{db}$ magyar harcjármű is megsérült a harcok során, a 12 db 38M Toldi könnyű harckocsiból 7 db javítható volt, de a $3 \mathrm{db} 39 \mathrm{M}$ Csaba páncélgépkocsi olyan sérüléseket szenvedett, hogy a tábori javítómühelyben már nem lehetett őket megjavítani.

Július 25-én az 5. gépkocsizó lövészzászlóalj heves harcokat vívott szovjet csapatokkal. A gépkocsizó lövészek harcát az 1 . lovas tüzérosztály $8 \mathrm{~cm}$-es tábori ágyúiból közvetlen irányzással leadott tủzcsapásokkal támogatták. A 2. gépkocsizó lövészdandár július 24-én Tulchin irányába tört

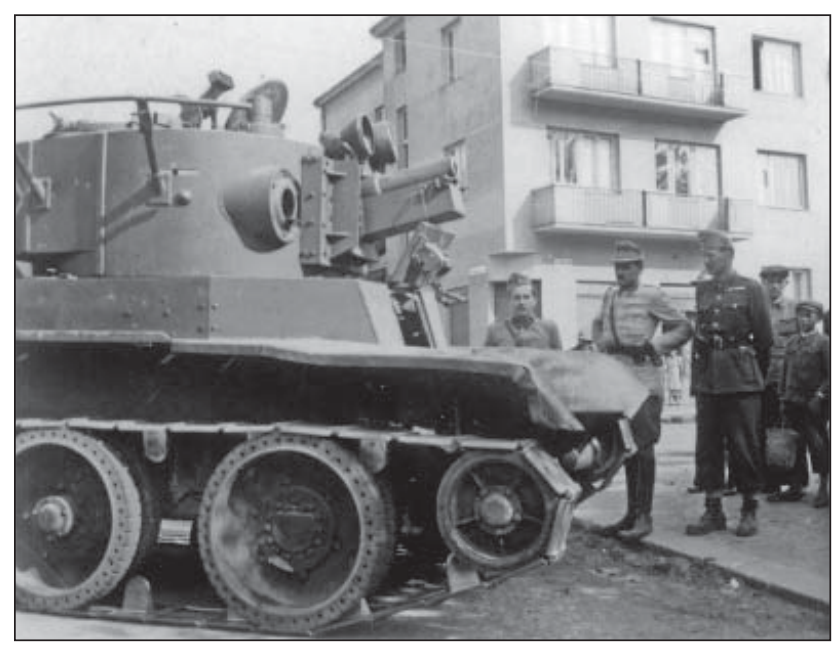

10. ábra. Egy zsákmányolt szovjet BT-7A harckocsit vizsgálnak magyar tisztek egy ukrán városban, 76 mm-es rövid csövü tarackkal a harckocsitoronyban

előre. A védekező szovjet erők a beérkező erősítések következtében számos ellentámadást hajtottak végre a magyar csapatok ellen. A 2. gépkocsizó lövészdandár csapatai elakadtak a sáros úton Gordievka körzetében. A dandár jobb szárnyán a román 8 . lovasdandár 3. lovasezrede helyezkedett el, de egy szovjet ellentámadást követően visszavonultak a román csapatok. A 2. gépkocsizó dandár jobb szárnya védtelen maradt, ezt felismerve a dandárparancsnok a 11. kerékpáros harckocsizászlóaljat vetette be, a szárnybiztosításra. A gyorshadtest parancsnoka elrendelte, hogy az 1. gépkocsizó lövészdandár és az 1. lovas páncéloszászlóalj erői is támogassák a sárban elakadt 2. gépkocsizó lövészdandár csapatait. A nagy sárban az 1. gépkocsizó lövészdandár alakulatai csak nagy nehézségek árán, a gép- és harcjárművek elé fogott lovak és tehenek segítségével vontatott jármüvekkel sikerült előrejutniuk a felázott, úttalan utakon.

Az 1. gépkocsizó lövészdandár egységei július 27-én éjszaka érkeztek be az alkalmazási területükre és menetből, a beérkezés sorrendjében kerültek harcbavetésre. A Bug folyó nyugati partját, heves harcok után július 29-ére sikerült megtisztítani a szovjet csapatoktól. A magyar csapatok súlyos veszteségeket szenvedtek a nem megfelelően koordinált és tüzérséggel nem támogatott ellentámadások során.

Az 1. lovas páncéloszászlóalj két kisharckocsi-századát július 27-én Révhegyi ezredes, a zászlóalj parancsnoka vetette harcba a Budy körzetében támadó szovjet csapatok megállítására. A harcok következtében az egyik 35M FIAT Ansaldo kisharckocsikkal felszerelt század szinte teljesen megsemmisült. A kisharckocsi-századokat egy repceföldön vetették be, ahol a sűrű aljnövényzet rátekeredett a gyenge motorral ellátott Ansaldo kisharckocsik lánctalpára és a harckocsimotorok lefulladtak. A 35M FIAT Ansaldo kisharckocsi motorjának beindítása csak a harcjárműből való kiszállás, és kézi „krublizás” útján volt megvalósítható. Ez azt jelentette, hogy az egyik kezelőnek ellenséges tűzben ki kellett mászni a járműből és egy kézi indító kurblival be kellett volna indítani a harckocsit. A magyar kisharckocsi-századokat nem támogatta kísérő gyalogság és a magyar harckocsizók kiváló célpontot nyújtottak a szovjet mesterlövészeknek. A támadásban résztvevő egyik kisharckocsi-század 23 darab 35M FIAT Ansaldo kisharckocsijából 18 harcjárművet kilőttek vagy elfoglaltak a szovjet csapatok. A támadáshoz besoroló utolsó harckocsiszakasz parancsnoka még időben észrevette, hogy a 


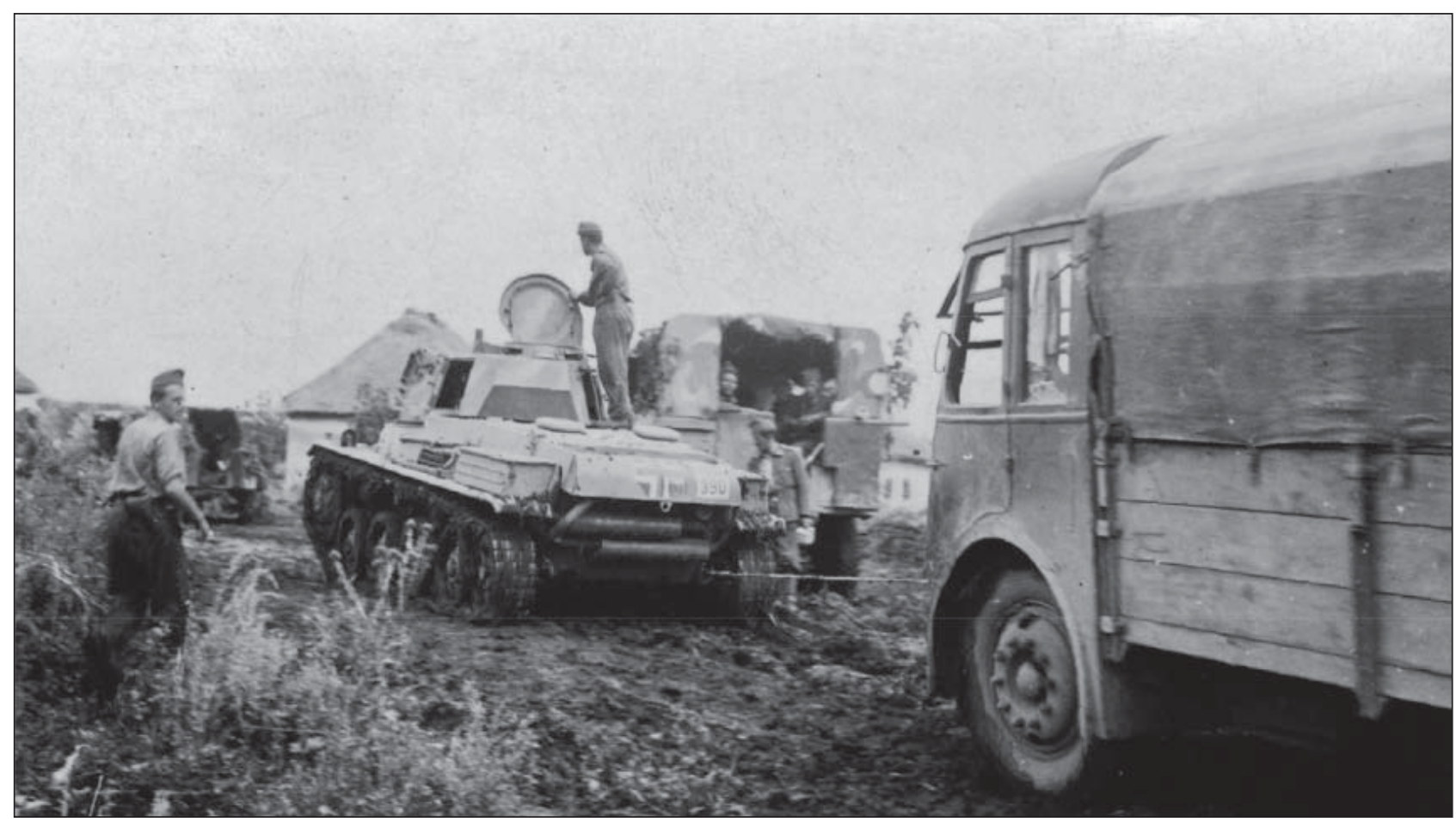

11. ábra. Egy 38M Toldi könnyü harckocsi egy sárban elakadt, olasz gyártmányú tehergépkocsit vontat

repceföldön szétbontakozó kisharckocsik elakadnak a növényzetben, ezért kifordult és visszavonult a támadásból. A másik kisharckocsi-század 11 meglévő Ansalo kisharckocsijából 6 db maradt harcképes. A támadó kisharckocsiszázad parancsnokai álítólag jelezték a zászlóaljparancsnoknak, hogy a terep nem alkalmas a támadásra, de Révhegyi ezredes nem változtatott a kiadott parancsán. Ez a bevetés véglegesen bebizonyította, hogy a 35M FIAT Ansaldók már teljesen alkalmatlanok bármilyen harctéri feladat ellátására.

A gépkocsizó lövészzászlóalj katonái, a kisharckocsiszázadok sikertelen támadása után, Trostianczky körzetében csaptak össze a Vörös Hadsereg katonáival. A harcokban a gépkocsizó lövészek 13 halottat, 34 sebesültet és 4 fő eltüntet vesztettek.

A 2. gépkocsizó lövészdandár 1941. július 22. és 29. között a következő veszteségeket szenvedte el; 104 hősi

\section{2. ábra. Az 1. hegyivadász dandár, dandár közvetlen} páncélgépkocsi-szakaszának 39M Csaba páncélgépkocsija

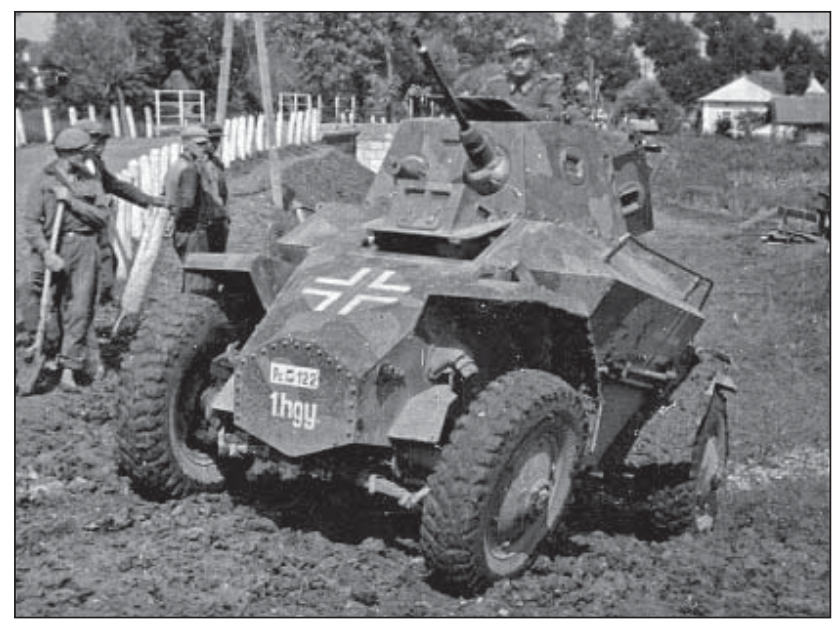

halott, 301 sebesült és 10 eltűnt katona, továbbá $32 \mathrm{db}$ harcképtelenné vált páncélos. A szovjet veszteség ebben az időszakban 515 elesett, 661 fogságba eset vöröskatona volt. A magyar csapatok $2 \mathrm{db}$ harcjárművet és $23 \mathrm{db}$ gépjárművet zsákmányoltak.

A július 27-i, gordievkai összecsapásban szenvedték el hadjárat a legsúlyosabb veszteségét a magyar páncéloscsapatok. A tiszti veszteség különösen magas volt, az ukrajnai hadmúveletek során összesen 8 páncélos tiszt halt hősi halált, 5 közülük a Gordievka környéki harcokban esett el. A harcok hevességére jellemző, hogy Antalffy Ferenc főhadnagy a 11. kerékpáros könnyűharckocsi-zászlóalj tisztje kézitusában halt hősi halált.

A hadjárat során elszenvedett technikai veszteségek pótlására július 27-én $14 \mathrm{db} 38 \mathrm{M}$ Toldi könnyű harckocsit, $9 \mathrm{db} 39 \mathrm{M}$ Csaba páncélgépkocsit és $5 \mathrm{db} 35 \mathrm{M}$ FIAT Ansaldo kisharckocsit indítottak útnak Magyarországról. A prioritást élvező német vasúti szállítmányok miatt a túlterhelt vasútvonalon a harcjárművek csak október 7-én érkeztek meg Krivoj-Rog-ba.

1941. július 29.-én a 3. gépkocsizó lövészzászlóalj egységei váratlanul tüzet kaptak a Bug folyó mentén, Bersad település közelében lévő dombos részről. A honvédek harcba léptek a dombot megszálló ellenségnek vélt erőkkel, akikről később bebizonyosodott, hogy németek voltak. A „,baráti tűz” 2 magyar és 4 német katona életébe került.

Augusztus 1-én az 1. gépkocsizó lövészdandár csapatai kétnapos utcai harcok után elfoglalták Pervomaysk városát. A honvédek 40 halottat és 100 sebesültet vesztettek. A harcok eredményeképpen a gépkocsizó lövészek 500 hadifoglyot ejtettek, 250 gépjárművet és 13 páncéltörő ágyút zsákmányoltak.

1941. augusztus 1-i állapot szerint a gyorshadtest haditechnikájából hiányzott 320 db motorkerékpár, 56 db személygépkocsi, 147 tehergépkocsi, $20 \mathrm{db}$ vontató, $8 \mathrm{db}$ páncélgépkocsi és $7 \mathrm{db}$ könnyű harckocsi.

Augusztus 5-én a csapatoknál $43 \mathrm{db}$ bevethető 38M Toldi könnyű harckocsi volt, további 14 könnyű harckocsi 
kiszálítás alatt volt a csapatokhoz. A tábori javítóműhelyekben 14 db 38M Toldi könnyű harckocsi várt javításra és 24 db könnyű harckocsi nem volt javítható tábori körülmények között.

Az 57 db 39M Csaba páncélgépkocsiból mindössze 20 $\mathrm{db}$ volt bevethető állapotban, 13 páncélgépkocsit a tábori javítóműhelyekben igyekeztek bevethetővé tenni, $20 \mathrm{db}$ javíthatatlan harcjármúvet pedig már útba is indítottak Magyarország felé, ahonnan gyári nagyjavítás után kerültek csak vissza a csapatokhoz.

$A z$ 1. lovasdandár az umani bekerítésben lévő szovjet csapatok ellen hajtott végre sikeres hadműveleteket. 1941. augusztus 6-án a lovasdandár parancsnoka, Vattay Antal vezérőrnagy utasította az 1. lovas páncéloszászlóalj felderítő páncélgépkocsi-századát hogy hajtson végre felderítést a bekerített szovjet csapatok irányába, Golovanevsk körzetében. A harcfelderítésre egy páncélgépkocsi-szakasz és egy kerékpáros szakasz lett kijelölve. A 3 db 39M Csaba páncélgépkocsi, és a vállalkozás parancsnoka Merész László tartalékos zászlós, szakaszparancsnok volt. Merész zászlós két páncélgépkocsival Moldovka irányába kezdte meg a felderítést, a harmadik páncélgépkocsit hátrahagyta a késésben lévő kerékpárosok bevárására. $A z$ előrenyomuló 39M Csaba páncélgépkocsik váratlanul belefutottak a bekerítésből kitörni készülő szovjet gépkocsizó és kozák lovas egységekbe. A toronyfegyvereikből folyamatosan tüzelő páncélgépkocsik meglepték, szétzilálták és visszavonulásra késztették a kitöréssel próbálkozó vöröskatonákat. A harcok hevességére jellemző, hogy a 39M Csaba páncélgépkocsik a teljes lőszer-javadalmazásukat elhasználták a tűzharcban. Merész László tartalékos zászlóst a harcban tanúsított magatartásáért a tiszti arany vitézségi éremmel tüntették ki.

1941. augusztus 10-11-én a gyorshadtest egységei ellen a szovjet légierő heves légitámadásokat hajtott végre Konstantinovka-Vosniesiensk körzetében. A légitámadások miatt 14 honvéd halt hősi halált és $12 \mathrm{db}$ páncélgépkocsi, $2 \mathrm{db}$ könnyű harckocsi és $10 \mathrm{db}$ gépjármű szenvedett kisebb-nagyobb sérüléseket. A királyi honvéd légierő, a magyar földi csapatokat oltalmazó vadászgépei $8 \mathrm{db}$ szovjet vadászgépet és $4 \mathrm{db}$ szovjet bombázót lőttek le egy saját vadászgép elvesztése árán.

1941. augusztus 16-17-én a gyorshadtest mindhárom dandárja részt vett Nikolajev elleni hadműveletekben. Augusztus 16-án a Mikecz Kálmán őrnagy által vezetett 4/ II. huszárosztály lovasrohamot intézett a védekező szovjet erők ellen. A támadást gépvontatású páncéltörő ágyús szakasz, egy huszárüteg (15/31M 7,5 cm-es lovasított hegyiágyúk) és egy páncélgépkocsi-szakasz 39M Csaba páncélgépkocsijai is támogatták, és sikerrel kivetették az állásaikból az ellenséget. A vöröskatonákat - a korabeli leírás szerint - valósággal sokkolta a lóháton támadó magyar huszárok látványa.

Augusztus 17. és 27. között a gyorscsapatok egy rövid pihenőhöz jutottak, rendezték az elmaradt karbantartásokat, kisebb javításokat, pihentették a kimerült személyi állományt.

Szeptember 1-ével a gyorshadtestet folyamvédelemre rendelték a Dnyeper folyónál, Dnyepropetrovszktól délre, egy 200 km hosszú szakaszon. A védőálás kiterjedése és a rendelkezésre álló erők nagysága nem tette lehetővé, hogy hézagmentesen megszállják a védővonalat. Vitéz dálnoki Miklós Béla vezérőrnagy utasításainak megfelelően a folyóparton laza, támpontszerű megfigyelőállásokat alakítottak ki. Ezeket az álásokat a kerékpáros, huszár és a lovaikat és gépjárműveiket elvesztő, gyalogosított alegységek szállták meg. Mögöttük, gyorsreagálású tartalékként a

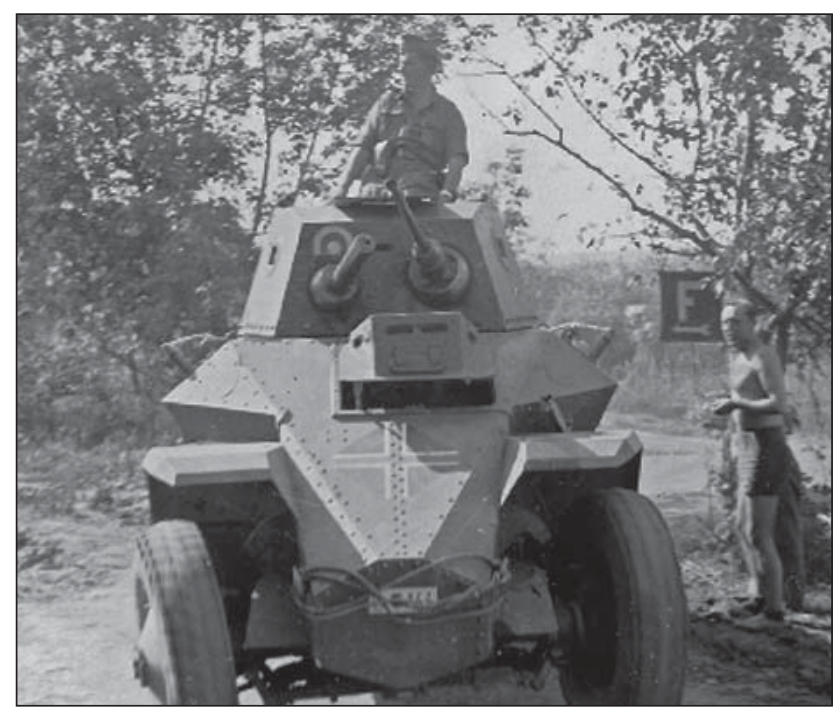

13. ábra. Az 1. lovas páncéloszászlóalj 39M Csaba páncélgépkocsija

páncélosokkal megerősített gépkocsizó lövészzászlóaljak és huszárosztályok helyezkedtek el. A 2. gépkocsizó lövészdandár egy $55 \mathrm{~km}$ hosszú védőállásért volt felelős, hozzá tartoztak a zaporozseci szigeten lévő állások is. Az 1. gépkocsizó lövészdandár egy 100 km hosszú sávot védett a folyóparton. Az Ankay-Anesini csoport két kerékpáros, két gépkocsizó lövész-, egy harckocsizózászlóalja és egy tüzérosztálya egy $45 \mathrm{~km}$-es szakasz védelméért felelt. Két lovasított huszárosztály tartalékban volt, a többi, lóval nem rendelkező gyalogosított huszárt a gyalogság megerősítésére a folyóparton lévő védőállásokba osztották be. Szeptember 5-én a zaporozseci hídfőben, a túlerőben lévő szovjet csapatok támadták meg a 2. gépkocsizó lövészdandár kimerült honvédjeit. A folyamatos támadások alatt összeomlott a magyar védelem és a gépkocsizó lövészek visszavonultak a folyó túlpartjára.

A gyorshadtest csapatait szeptember 27-én leváltották, és pihentetés, átszervezés céljából október 11-ig összevonták Tomakovkától délre. Október 10-én az 1. lovasdan-

14. ábra. Egy lengyel Sokol oldalkocsis motorkerékpár 36M 20 mm-es nehézpuskával felszerelve. A lengyel zsákmánymotorkerékpárok a felderítő-zászlóaljak motorkerékpáros századaiban szolgáltak

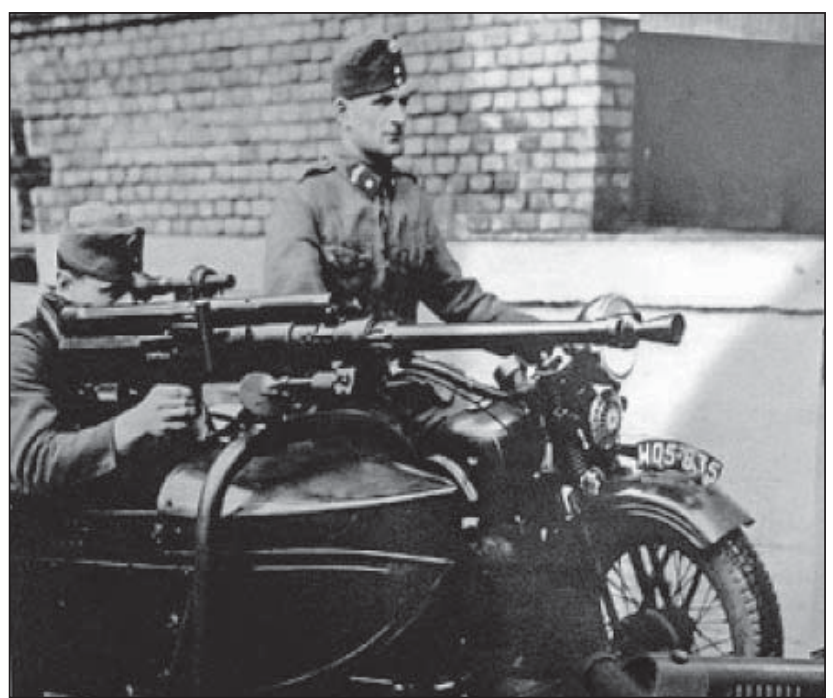


dár lovasított egységeit kivonták a gyorshadtest kötelékéből és hazaküldésükről intézkedtek. A gyorshadtest ebben az időszakban már csak két leharcolt gépkocsizó lövészdandárból állt, a dandárok kerékpáros zászlóaljai is már korábban kivonásra kerültek. A hadtest kerékpáros zászlóaljait a hadműveleti területen hátsó biztosítási feladatok elvégzésére alkalmazták.

1941 szeptemberében a kerékpáros könnyűharckocsizászlóaljak harcereje már csak egy 38M Toldi könnyű harckocsikkal felszerelt század volt. A páncéloscsapatoknak összesen 35-40 db bevethető könnyű harckocsija és páncélgépkocsija volt. A megmaradt személyi állományt és harcjárműveket az 1. lovas páncéloszászlóalj bázisán létrehozott tábori páncéloszászlóaljba vonták össze.

A gépkocsizó lövészzászlóaljak meglévő, harcoló alegységeit különböző harccsoportokba vonták össze. A harccsoportok alapját a leharcolt gépkocsizó lövészzászlóaljak alkották, megerősítve árkász-, tüzér- és légvédelmi tüzér rajokkal, szakaszokkal. Az 1. gépkocsizó lövészdandár állományába három harccsoport és két felderítő-osztag tartozott. A felderítő-osztagok és a harccsoportok támogatására könnyű harckocsikat osztottak be. A harctéri tapasztalatok alapján a 38M Toldi könnyű harckocsik gyorsaságuk és mozgékonyságuk miatt meglepetésszerű bevetésre alkalmasak voltak, de csak könnyű fegyverzettel ellátott ellenséggel szemben. Az 1. gépkocsizó lövészdandár 25 db 38M Toldi könnyű harckocsijából 10-10 db, két harccsoport támogatására, míg 5 db könnyű harckocsi az egyik felderítő-osztag megerősítésére került alkalmazásra.

1941. október 17-én a gyorshadtest még megmaradt és harcba vethető erői Isium irányába törtek előre. Az 1. gépkocsizó lövészdandár harccsoportjai heves harcok után elfoglalták Mecsebelovkát. Az elkeseredetten védekező és helyi ellentámadásokat indító szovjet erőket végül a dandárparancsnok által bevetett 38M Toldi könnyű harckocsik támadása törte meg.

Az előrenyomuló magyar csapatok 1941. október 28-29én, Isium-tól délre elérték a Donyec folyót. A német katonai vezetéssel folytatott tárgyalások eredményeként döntés született a gyorshadtest harcból való kiválásáról és hazahozataláról. 1941. november 6-án a gyorshadtest csapatai befejezték a harctevékenységüket és kiváltak az arcvonalból és megkezdték a gyülekezést és a felkészülést a hazatelepülésre.

A gyorshadtest csapatai 4 hónapos hadműveleti tevékenységük során, mintegy $2000 \mathrm{~km}$-t nyomultak elöre. A gyorshadtest személyi vesztesége nagyjából 10\%-os volt. Hősi halált halt 855 fő, 2845 fő megsebesült, 830 fő megbetegedett.

A harcok során a páncélos technikából a 35M FIAT Ansaldo kisharckocsik 100\%-a megsemmisült; a 39M Csaba páncélgépkocsik $90 \%$-a és a $38 \mathrm{M}$ Toldi könnyü harckocsik $80 \%$-a vált harcképtelenné. A harctérről a magyar csapatok az összes kilőtt vagy müszakilag lerobbant saját könnyű harckocsit és páncélgépkocsit hazaszállították. A bevetett $95 \mathrm{db}$ könnyü harckocsiból $62 \mathrm{db}$ szorult gyári nagyjavításra, közülük $25 \mathrm{db}$ kilőtt járművet kellett javítani. A csapatok 1200 db gépjármúvet, 28 db löveget is elvesztettek a harcok során.

\section{ForRÁsOK}

A m. kir. Fegyveres erők képes krónikája (1919-1945), Vitézi Szék, 1977;

Adonyi-Náredny Ferenc - Nagy Kálmán: Magyar huszárok a II. világháborúban, HHA, 1990;
Babucs Zoltán: Jászsági honvédek a II. világháborúban, I. A jászberényi harckocsi zászlóalj története a II. világháborúban, 2000;

Babucs Zoltán - Maruzs Roland: „Jász vitézek rajta, előre!” A jászberényi kerékpáros és harckocsizó zászlóalj története 1920-1944, Puedlo;

Bíró Ádám - Éder Miklós - Sárhidai Gyula: A Magyar Királyi Honvédség külföldi gyártású páncélos harcjárművei 1920-1945, Petit Real, 2006;

Bíró Ádám - Éder Miklós - Sárhidai Gyula: A magyar királyi honvédség hazai gyártású páncélos harcjárművei 1920-1945, Petit Real, 2012;

Bombay László - Gyarmati József - Turcsányi Károly: Harckocsik 1916-tól napjainking, Zrínyi;

Bonhardt Attila - Sárhidai Gyula - Winkler László: A Magyar Királyi Honvédség fegyverzete 1919-45 part 1, Zrínyi, 1992;

Dálnoki Veress Lajos: Magyarország honvédelme a II. világháború előtt és alatt (1920-1945), München, 1974;

Dombrády Loránd - Tóth Lajos: Magyar Királyi Honvédség 1919-45, Zrínyi, 1987;

Dombrády Loránd: A magyar gazdaság és a hadfelszerelés, 1938/44, Akadémia, 1981;

Csernavölgyi Antal: Az aranycsillag rabjai, 1994;

Csima János: Források a Magyar Honvédség II. világháborús történetének tanulmányozásához, Zrínyi, 1961;

Gosztonyi Péter. A Magyar Honvédség a II. világháborúban, Európa, 1992;

Görgey Vince: Páncélosok előre!, Stádium, 1942;

Horváth Csaba: A magyar katonai felderítés története a kezdetektől 1945-ig, Puedlo;

Magyarország a II. világháborúban, Enciklopédia, PETIT REAL, 1997;

Szabó Péter - Számvéber Norbert: A keleti hadszíntér és Magyarország 1941-1943, Puedlo;

Stark: Hadak Útján, Corvina, 1991;

Sőregi Zoltán - Végső István: Gyorsan, bátran, hüséggel, A m. kir. „Balogh Ádám” 15. honvéd kerékpáros zászlóalj története, Timp Kiadó 2009;

Ungváry Krisztián: A magyar honvédség a második világháborúban, Osiris, 2005;

Dr. Varga D. József: Magyar autógyárak katonai járművei Maróti, 2008;

Dr. Lengyel Ferencz: M. kir. I. Gyors Hadtest hadműveletei a Szovjetúnió elleni háborúban 1941 július 9. - november 15., ZMNE Egyetemi jegyzet, 1994/204 o.

Tóth Lajos: A Gyorshadtest a Szovjetunióban, Hadtörténeti Közlemények 1966/2;

Dombrándy Loránd: A horthysta katonai vezetés erőfeszítései a páncélos fegyvernem megteremtésére, Hadtörténeti Közlemények 1969/2., 1970/4.;

Bíró Ádám: The AC-II, 39M Csaba páncélgépkocsik, Haditechnikai Szemle 1992/3.;

Bíró Ádám: A magyar páncélos fegyvernem kezdetei, 2. rész, a FIAT Ansaldo 35M, Haditechnikai Szemle 1993/3;

Simon Tamás: Az 1. gépkocsizó dandár a nyikolajevi csatában, Katona UUjság 2013/4.;

Éder Miklós: 38M Toldi könnyűharckocsi, Militaria Modell 1991/3.;

Éder Miklós: 39M Csaba páncélgépkocsi, Militaria Modell 1992/1.;

Csaba Becze: Magyar steel, Mashroom Publication, 2006.

Peter Gosztonyi: Deutschlands waffengefahrten an de rost front 1941, Motorbuch Verlag, 1981.;

Nigel Thomas - László Pál Szabó: The Royal Hungarian Army in World War II, Ospery, 2008. 